\title{
Effects of super-absorbent polymers on a soil-wheat (Triticum aestivum L.) system in the field
}

\author{
Xi Li ${ }^{a, b}$, Ji-Zheng He ${ }^{a, c}$, Jane M. Hughes ${ }^{c}$, Yu-Rong Liu ${ }^{a}$, Yuan-Ming Zheng ${ }^{a, *}$ \\ a State Key Laboratory of Urban and Regional Ecology, Research Center for Eco-environmental Sciences, Chinese Academy of Sciences, Beijing 100085, China \\ b University of Chinese Academy of Sciences, Beijing 100049, China \\ c Griffith School of Environment, Environmental Futures Centre, Griffith University, Nathan, Queensland 4111, Australia
}

\section{A R T I C L E I N F O}

\section{Article history:}

Received 15 January 2013

Received in revised form 13 August 2013

Accepted 14 August 2013

\section{Keywords:}

Super-absorbent polymers

Winter wheat

Maximum hygroscopic moisture

Soil microbial biomass carbon

Soil microbial respiration

Field test

\begin{abstract}
A B S T R A C T
Super-absorbent polymers (SAPs) have been established as a soil conditioner to reduce soil water loss and increase crop yield. However, there are few studies about how SAPs affect the soil microbial community. In this study, two types of SAPs, Jaguar C (JC) and Jaguar S (JS), were applied at $200 \mathrm{~kg} \mathrm{ha}^{-1}$ by bulk and spraying treatments in a field trial to investigate their effects on winter wheat growth, the soil's physical properties and microbial abundance and activity. It was found that the addition of SAPs promoted the formation of macro soil aggregates (particle size $>0.25 \mathrm{~mm}$ ) and soil bacterial abundance under winter wheat cultivation. SAPs also significantly increased the soil water content (SWC) and soil maximum hygroscopic moisture (SMHM) in the booting and filling stages but had no effects on the soil available water-holding capacity (AWC) compared with the control in the filling stage. The effects of SAPs depended on the application strategy, as only the bulkJC treatment improved the wheat yield, soil microbial biomass carbon (MBC) and soil microbial respiration (SMR). The results showed that the application of SAPs did not lead to detectable adverse effects on the soil microbial community and might even enhance soil microbial activity. This study should serve as a useful complementary exploration for the assessment of the environmental effects of soil additives.
\end{abstract}

(c) 2013 Elsevier B.V. All rights reserved.

\section{Introduction}

Eighty percent of available water resources in the world are currently used to support irrigated agriculture (Wallace, 2000). As a result of the water resource crisis, water-saving agriculture is essential for the sustainable development of human societies. Furthermore, droughts are predicted to be increasingly severe due to climate change (Gornall et al., 2010). China is the world's most populous country and one of the most impoverished countries in terms of water resources per capita, which suggests that people may be more concerned with water shortages, especially in North and Northwest China. Therefore, new effective water-saving measures are urgently needed. Super-absorbent polymers (SAPs) may help ameliorate this crisis.

SAPs are hydrophilic networks that can absorb and retain 1000 times more water or aqueous solutions than their original size and weight (Sojka and Entry, 2000). Thus, the application of SAPs to soil may increase water-holding capacities and nutrient utilization efficiency (Lentz and Sojka, 1994; Lentz et al., 1998) and reduce water loss (Al-Omran and Al-Harbi, 1997). Previous studies on SAPs

\footnotetext{
* Corresponding author. Tel.: +8610 62849500; fax: +86 1062923563 .

E-mail address: zhengym@rcees.ac.cn (Y.-M. Zheng).
}

have been focused on their effects on particular soil physical and chemical properties (Nadler et al., 1996; Zhang and Miller, 1996), such as pH, electrical conductivity (EC) and soil water content (Bai et al., 2010), for soil erosion control and irrigation management (Sojka et al., 1998) and to study the effects on plant growth and production (Busscher et al., 2009; Islam et al., 2011a). However, few studies have investigated the effects of SAPs on soil microorganisms and plant available water in the natural environment.

In this study, we examined the changes in the soil physical properties, soil microbial activity and biomass that occurred after SAPs were applied in the field during wheat growth. The aim of this study was to provide fundamental information about the impacts of SAPs on the natural environment and the establishment of a framework for environmental safety assessment for soil additives.

\section{Materials and methods}

\subsection{Field experimental setup and sampling}

The field experiments were conducted in Linfen City, Shanxi Province, China. The site is located at the eastern edge of the Loess Plateau and has a typical semi-arid continental monsoon climate. The soil was a loam with an organic matter carbon of $0.8 \%$, pH of 7.6 
Table 1

Characteristics of the super-absorbent polymers (SAPs).

\begin{tabular}{|c|c|c|c|c|c|}
\hline SAP & Manufacturer & Component & Ingredient compatibility & Particle size range $(\mathrm{mm})$ & Color \\
\hline $\mathrm{JC}$ & Rhodia Co., Ltd, France & 2-hydroxypropyl 2-hydroxy-3-propyl ether & $\begin{array}{l}\text { Anionic, cationic, nonionic and } \\
\text { amphoteric surfactants }\end{array}$ & $0.05-0.09$ & Yellow \\
\hline JS & Rhodia Co., Ltd, France & physcion-1-glucosylrham-noside & $\begin{array}{l}\text { Anionic, cationic, nonionic and } \\
\text { amphoteric surfactants }\end{array}$ & $0.06-0.08$ & Off-white \\
\hline
\end{tabular}

and CEC of $13.2 \mathrm{cmol} \mathrm{kg}$ and is classified as cinnamon soil (Luvisols) in Chinese soil taxonomy or Alfisols in USA soil taxonomy.

The experimental field was divided into five plots. One plot was set as the control (without SAPs), and others were randomly assigned the various SAP treatments. Each plot ( $5 \mathrm{~m}$ by $5 \mathrm{~m}$ ) was further divided into four equal subplots as replicates, resulting in 20 subplots in total. Chinese winter wheat (Triticum aestivum L.), a typical crop and species for this area, was obtained from the Institute of Wheat Research of Linfen City, Shanxi Province.

Two SAPs extracted from natural guar gum, Jaguar C (JC) and Jaguar S (JS), were obtained from Rhodia Co., France (Table 1). The treatments included the control (CK, without any SAPs), JS with spraying application (JS-S), JC with spraying application (JCS), JS with bulk application (JS-B) and JC with bulk application (JC-B). Approximately $0.4 \mathrm{~m}^{3}$ of water was irrigated for each subplot according to the local irrigation regime. For the control, pure water was irrigated without SAP application. For the bulk application, the surface soil collected from a depth of $1 \mathrm{~cm}$ in each subplot was mixed with SAPs and cast evenly at an SAP concentration of $200 \mathrm{~kg} \mathrm{ha}^{-1}$. Next, $0.4 \mathrm{~m}^{3}$ of water was irrigated for each subplot. For spraying application, $0.4 \mathrm{~m}^{3}$ of the mixture of SAPs and water was sprayed onto the surface soil of each subplot.

The wheat was sowed on October 20th, 2010. Its dormancy stage was from November 2010 to February 2011. During this period, we only observed the crop growth. On March 7th, 2011, SAPs were applied to the soil, as the crop had recovered from the cold winter and began to grow. Soil samples were collected at three important stages: the jointing stage (sampled on March 11th, 2011), booting stage (April 26th, 2011) and filling stage (June 7th, 2011). Samples were collected using a core sampler at a depth of $0-10 \mathrm{~cm}$ and a distance of $1-5 \mathrm{~cm}$ from the plant. Five sub-samples from each subplot were mixed to obtain a composite sample. The samples were passed through an $8 \mathrm{~mm}$ sieve for the soil water-stable aggregates analysis and through a $2 \mathrm{~mm}$ sieve and kept at $4{ }^{\circ} \mathrm{C}$ and $-20^{\circ} \mathrm{C}$ for the analysis of other soil physical properties and microbial properties, respectively. The shoot lengths of plants in the three stages and the grain dry weights after harvest were measured.

\subsection{Determination of soil water-stable aggregates (WSA)}

The separation of soil aggregates into different sizes $(<0.25 \mathrm{~mm}$, 0.25-0.5 mm, 0.5-1 mm, $1-2 \mathrm{~mm}, 2-5 \mathrm{~mm}$ and $>5 \mathrm{~mm}$ ) was achieved using the wet sieving method according to Elliot (Elliot, 1986). Briefly, a $100 \mathrm{~g}$ sample was immersed in water at room temperature on the largest screen $(2 \mathrm{~mm})$ for $5 \mathrm{~min}$ before sieving commenced. The soils were sieved under water by gently moving the sieve vertically 50 times over a period of 2 min through water contained in a sedimentation cylinder. The recoveries from the wet sieving were $>97 \%$ by weight in all cases. The weight of each WSA fraction was expressed as the proportion of the sum of the fraction weights.

\subsection{Soil maximum hygroscopic moisture (SMHM) and soil available water-holding capacity (AWC) assay}

First, $10 \mathrm{~g}$ of dry soil in a $25 \mathrm{~mL}$ beaker was placed in a desiccator, the bottom of which was saturated with $\mathrm{K}_{2} \mathrm{SO}_{4}$ solution.
The desiccator was kept at a stable temperature $\left(20^{\circ} \mathrm{C}\right)$. After one week of moisture absorption, the beaker was removed, weighed and returned to the desiccator. This procedure was repeated several times until the weight of the beaker with the soil stabilized. The beaker (containing the soil sample) was then placed in an oven at $105 \pm 2{ }^{\circ} \mathrm{C}$ for $18 \mathrm{~h}$. The natural water content method was used to calculate the SMHM. The SMHM can be used to estimate the soil available water-holding capacity (AWC) (Gupta and Larson, 1979) for the plant using the following equation: $A W C=S W C-2 * S M H M$, where SWC is the soil water content.

\subsection{Soil DNA extraction and real-time PCR assay of bacterial abundance}

Nucleic acids were extracted from $0.5 \mathrm{~g}$ of fresh soil using a MoBio UltraClean ${ }^{\mathrm{TM}}$ soil DNA isolation kit (San Diego, CA) according to the manufacturer's protocol with a minor modification (He et al., 2007). The extracted DNA was stored at $-20^{\circ} \mathrm{C}$ before use.

The abundances of bacteria were determined using the quantitative real-time PCR method targeting the 16S rRNA gene in an iCycler iQ5 thermocycler (Bio-Rad, USA) (He et al., 2007), with the primer pairs BACT 1369F (5'-CGGTGAATACGTTCYCGG-3')/PROK 1492R (5'-GGWTACCTTGTTACGACTT-3') and Probe TM 1389F (5'CTTGTACACACCGCCCGTC-3') (Suzuki et al., 2000). Real-time PCR was performed in a $25 \mu \mathrm{L}$ reaction volume containing $12.5 \mu \mathrm{L}$ of $2 \times$ Premix Ex Taq (TaKaRa Biotechnology, Otsu, Shiga, Japan), $100 \mathrm{nM}$ of each primer, $120 \mathrm{nM}$ of the probe, and $1 \mu \mathrm{L}$ of the $10-$ fold-diluted DNA template (1-10 ng). The amplification conditions were as follows: $95^{\circ} \mathrm{C}$ for $10 \mathrm{~s}, 35$ cycles of $15 \mathrm{~s}$ at $95^{\circ} \mathrm{C}, 1 \mathrm{~min}$ at $56^{\circ} \mathrm{C}$.

\subsection{Soil microbial biomass carbon (MBC) analyses}

The soil microbial biomass was determined using the chloroform fumigation extraction method (Vance et al., 1987). For this analysis, each fresh soil sample was divided into eight portions. Four of these portions (each containing $10 \mathrm{~g}$ on an oven-dry basis) were placed into $100 \mathrm{~mL}$ glass bottles, and chloroform fumigation was performed with the addition of ethanol-free chloroform ( $10 \mu \mathrm{Lg}^{-1}$ oven-dry soil). The soils were then mixed thoroughly and spread thinly on the inner surface of the bottle. The soils were further fumigated with chloroform for $24 \mathrm{~h}$ at $30^{\circ} \mathrm{C}$ in desiccators. After fumigant removal, the soils were extracted with $40 \mathrm{~mL}$ of $0.5 \mathrm{M} \mathrm{K}_{2} \mathrm{SO}_{4}$ for $30 \mathrm{~min}$. The other four non-fumigated soils were extracted similarly at the onset of fumigation. The microbial biomass carbon (MBC) was estimated as the difference in $\mathrm{K}_{2} \mathrm{SO}_{4}$ extractable dissolved organic carbon (C) between the fumigated and unfumigated soils using the extractability correction factor: $K_{C}=0.45$ for C (Jonasson et al., 1996; Rinnan et al., 2008). The extracted $\mathrm{C}$ was then determined using a total dissolved organic carbon analyzer (TOC-Vesh).

\subsection{Determination of soil microbial respiration (SMR)}

Soil respiration was measured using the method described by Chen et al. (2000). Fresh soil (20 g dry weight equivalent) was placed 

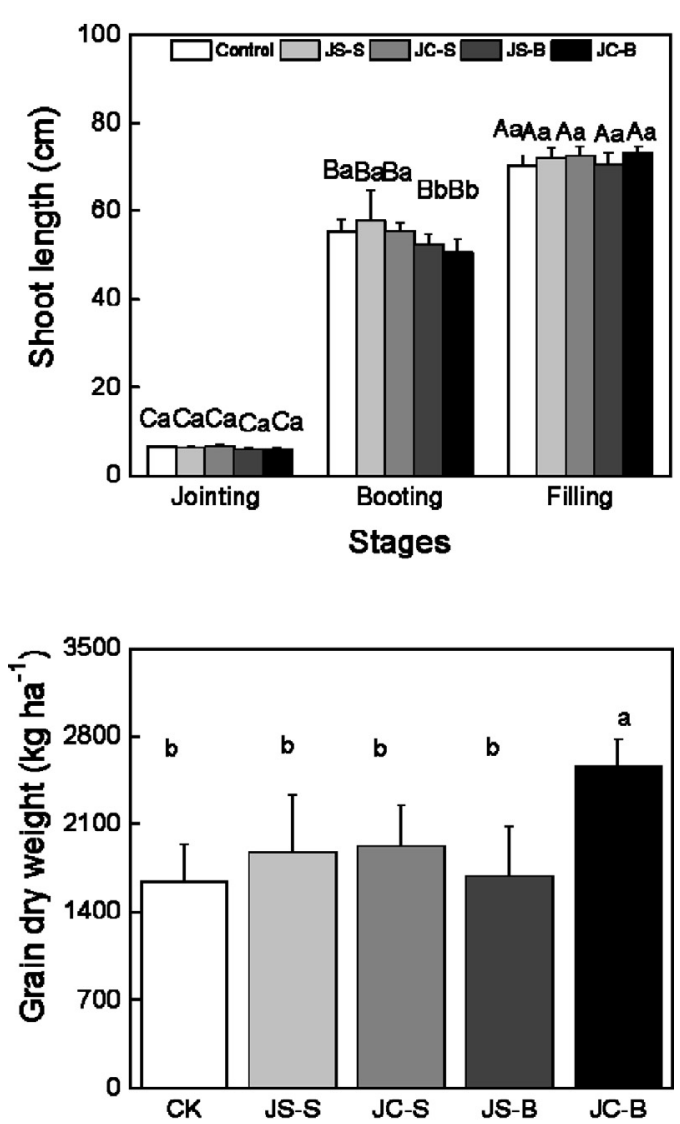

Fig. 1. Plant shoot length and grain dry weight of Chinese wheat plants in different stages and under different SAP treatments. Different capital letters indicate significant differences between stages for the same SAP treatment $(P<0.05)$. Different lowercase letters indicate significant differences between SAP treatments in the same growth stage $(P<0.05)$. Small bars indicate the standard errors.

in a sealed $500 \mathrm{~mL}$ glass bottle and incubated at $22^{\circ} \mathrm{C}$ for $24 \mathrm{~h}$. The carbon dioxide derived from the soil was trapped in $0.1 \mathrm{M} \mathrm{NaOH}$ and measured by titration with $0.1 \mathrm{M} \mathrm{HCl}$ to the phenolphthalein end point after the addition of $1 \mathrm{M} \mathrm{BaCl}_{2}$. Numerous controls (i.e., the glass bottle without soil) were subjected to the same conditions and used as blanks. The amount of carbon dioxide derived was calculated from the difference in molarity between the $\mathrm{NaOH}$ from the blanks and samples.

\subsection{Data processing and statistical analysis}

Statistical analysis was performed using SPSS 17.0 (SPSS Inc., Chicago, IL, USA). Multivariate analysis of variance (ANOVA) followed by LSD and SNK test was used to check the differences between treatments. $P<0.05$ was considered to be statistically significant.

\section{Results}

\subsection{Plant properties}

The plants grew quickly from the jointing to the booting stage and more slowly from the booting to the filling stage (Fig. 1). The shoot lengths of the plants showed significant differences between the three stages, but the effect of SAPs was minimal. Only JC-B significantly increased the total grain dry weight $(56 \% ; P<0.05)$.
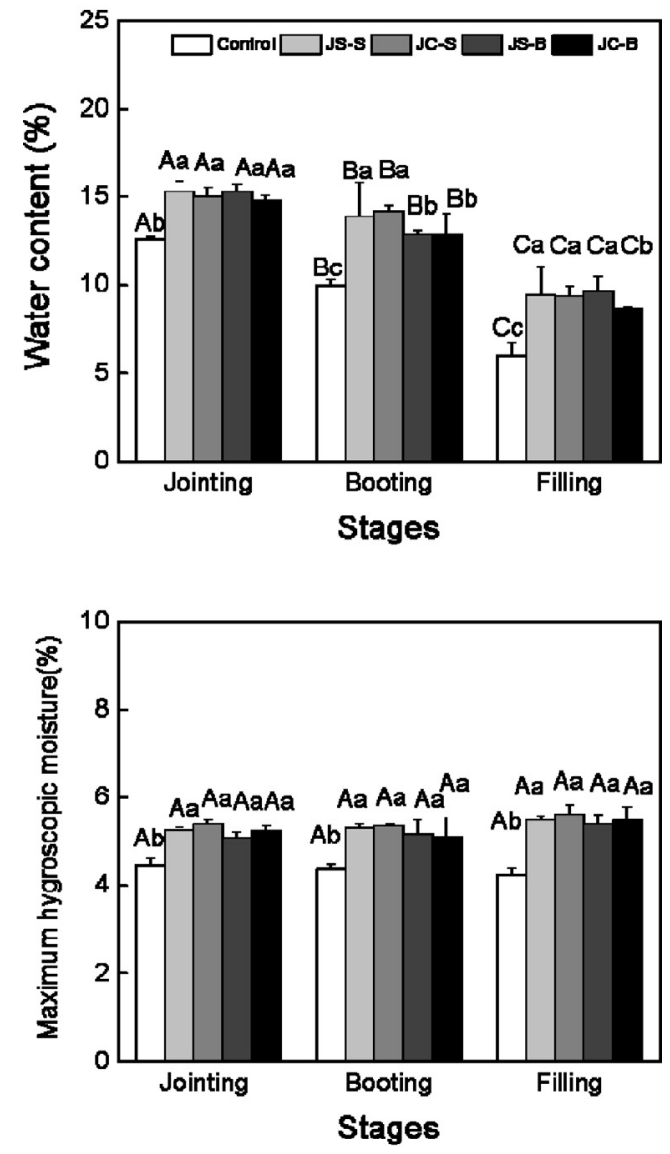

Fig. 2. Soil water content (SWC) and maximum hygroscopic moisture (SMHM) in different stages and under different SAP treatments. Different capital letters indicate significant differences between stages for the same SAP treatment $(P<0.05)$. Different lowercase letters indicate significant differences between SAP treatments in the same growth stage $(P<0.05)$. Small bars indicate the standard errors.

\subsection{Soil water-stable aggregates}

Table 2 shows the variation of soil water-stable aggregates throughout wheat growth and among treatments. There were significant differences in the soil particle sizes between the first stage and the second or third stage $(P<0.05)$. SAP application significantly increased the macro soil aggregates (particle size $>0.25 \mathrm{~mm}$ ) compared with the control in the booting and filling stages, while the differences between the two SAPs treatments were not significant.

\subsection{SWC, SMHM and AWC}

The SWC differed by SAP treatment and growth stage, whereas the SMHM only differed by SAP treatment (Fig. 2). In the jointing, booting and filling stages, all SAP treatments significantly increased the SWC compared with the control $(P<0.05)$. There were also significant differences for the SWC between SAP treatments, especially in the booting stage. The effects of the spraying treatments were greater than those of the bulk treatments. Similarly, all SAP treatments significantly increased SMHM compared with the control in the three stages $(P<0.05)$. However, differences in SMHM by SAP were not observed.

As shown in Fig. 3, there were obvious effects on AWC in the first two wheat growth stages and among the SAP treatments. The values of AWC in the filling stage were negative, indicating that the soil water could not be used by plants at all in this stage. This decline of AWC during wheat growth was very similar to that 
Table 2

Water-stable soil aggregate composition at different stages and under different treatments ${ }^{\mathrm{a}}$.

\begin{tabular}{|c|c|c|c|c|c|c|c|c|c|}
\hline \multirow[t]{2}{*}{ Application method } & \multicolumn{6}{|c|}{ Soil water-stable aggregate content (\%) } & \multicolumn{3}{|l|}{ Subtotal } \\
\hline & $<0.25 \mathrm{~mm}$ & $0.25-0.5 \mathrm{~mm}$ & $0.5-1 \mathrm{~mm}$ & $1-2 \mathrm{~mm}$ & $2-5 \mathrm{~mm}$ & $>5 \mathrm{~mm}$ & $>0.25 \mathrm{~mm}$ & $>0.5 \mathrm{~mm}$ & $>1 \mathrm{~mm}$ \\
\hline \multicolumn{10}{|l|}{ Jointing stage } \\
\hline $\mathrm{C}$ & $47.0 \mathrm{Aa}$ & 16.4 Aa & 10.6 Аa & $7.9 \mathrm{Aa}$ & $8.9 \mathrm{Aa}$ & $9.2 \mathrm{Aa}$ & $53.0 \mathrm{Aa}$ & 36.6 Аа & $26.0 \mathrm{Aa}$ \\
\hline JS-S & 45.7 Ba & 17.0 Ba & 10.7 Ba & 8.6 Ba & 8.7 Ba & $9.3 \mathrm{Ba}$ & $54.3 \mathrm{Ba}$ & 37.3 Ba & $26.6 \mathrm{Ba}$ \\
\hline JC-S & $46.0 \mathrm{Ba}$ & 17.0 Ba & $10.8 \mathrm{Ba}$ & $8.3 \mathrm{Ba}$ & $8.9 \mathrm{Ba}$ & $9.0 \mathrm{Ba}$ & $54.0 \mathrm{Ba}$ & $37.0 \mathrm{Ba}$ & $26.2 \mathrm{Ba}$ \\
\hline JS-B & $44.8 \mathrm{Ba}$ & 17.1 Ba & $10.8 \mathrm{Ba}$ & $8.6 \mathrm{Ba}$ & $9.1 \mathrm{Ba}$ & $9.5 \mathrm{Ba}$ & $55.2 \mathrm{Ba}$ & $38.0 \mathrm{Ba}$ & $27.2 \mathrm{Ba}$ \\
\hline JC-B & $45.5 \mathrm{Ba}$ & 17.0 Ba & 10.6 Ba & $8.4 \mathrm{Ba}$ & $9.0 \mathrm{Ba}$ & $9.5 \mathrm{Ba}$ & $54.5 \mathrm{Ba}$ & 37.5 Ba & 26.9 Ba \\
\hline \multicolumn{10}{|l|}{ Booting Stage } \\
\hline $\mathrm{C}$ & $46.1 \mathrm{Aa}$ & $17.0 \mathrm{Ab}$ & $11.0 \mathrm{Ab}$ & 7.6 Ab & $8.9 \mathrm{Ab}$ & $9.5 \mathrm{Ab}$ & $54.0 \mathrm{Ab}$ & $37.0 \mathrm{Ab}$ & $26.0 \mathrm{Ab}$ \\
\hline JS-S & $28.4 \mathrm{Ab}$ & $20.5 \mathrm{Aa}$ & $19.8 \mathrm{Aa}$ & $9.8 \mathrm{Aa}$ & $10.4 \mathrm{Aa}$ & $11.2 \mathrm{Aa}$ & $71.6 \mathrm{Aa}$ & $51.1 \mathrm{Aa}$ & $31.4 \mathrm{Aa}$ \\
\hline JC-S & $27.3 \mathrm{Ab}$ & $20.5 \mathrm{Aa}$ & $20.0 \mathrm{Aa}$ & $9.8 \mathrm{Aa}$ & $10.6 \mathrm{Aa}$ & $11.8 \mathrm{Aa}$ & $72.8 \mathrm{Aa}$ & $52.2 \mathrm{Aa}$ & $32.2 \mathrm{Aa}$ \\
\hline JS-B & $27.3 \mathrm{Ab}$ & 19.9 Aa & $20.3 \mathrm{Aa}$ & $9.8 \mathrm{Aa}$ & 10.7 Aa & $12.0 \mathrm{Aa}$ & $72.7 \mathrm{Aa}$ & $52.9 \mathrm{Aa}$ & $32.5 \mathrm{Aa}$ \\
\hline JC-B & $26.5 \mathrm{Ab}$ & $20.1 \mathrm{Aa}$ & $20.2 \mathrm{Aa}$ & $10.3 \mathrm{Aa}$ & $10.5 \mathrm{Aa}$ & $12.3 \mathrm{Aa}$ & $73.5 \mathrm{Aa}$ & $53.4 \mathrm{Aa}$ & $33.2 \mathrm{Aa}$ \\
\hline \multicolumn{10}{|l|}{ Filling stage } \\
\hline $\mathrm{C}$ & $45.6 \mathrm{Aa}$ & $17.0 \mathrm{Ab}$ & $10.8 \mathrm{Ab}$ & $7.5 \mathrm{Ab}$ & $9.0 \mathrm{Ab}$ & $10.0 \mathrm{Ab}$ & $54.4 \mathrm{Ab}$ & $37.4 \mathrm{Ab}$ & $26.6 \mathrm{Ab}$ \\
\hline JS-S & $26.3 \mathrm{Ab}$ & $20.4 \mathrm{Aa}$ & $20.2 \mathrm{Aa}$ & $10.1 \mathrm{Aa}$ & 11.1 Aa & $12.0 \mathrm{Aa}$ & 73.7 Aa & $53.3 \mathrm{Aa}$ & $33.2 \mathrm{Aa}$ \\
\hline JC-S & $25.9 \mathrm{Ab}$ & 19.9 Aa & $21.0 \mathrm{Aa}$ & $10.0 \mathrm{Aa}$ & 11.2 Aa & $12.0 \mathrm{Aa}$ & 74.2 Aa & $54.3 \mathrm{Aa}$ & $33.2 \mathrm{Aa}$ \\
\hline JS-B & $25.8 \mathrm{Ab}$ & $20.3 \mathrm{Aa}$ & $20.6 \mathrm{Aa}$ & $9.9 \mathrm{Aa}$ & 11.2 Aa & $12.2 \mathrm{Aa}$ & $74.2 \mathrm{Aa}$ & 53.9 Аа & $33.3 \mathrm{Aa}$ \\
\hline JC-B & $26.2 \mathrm{Ab}$ & $19.8 \mathrm{Aa}$ & $20.1 \mathrm{Aa}$ & $10.8 \mathrm{Aa}$ & $10.9 \mathrm{Aa}$ & $12.2 \mathrm{Aa}$ & $73.8 \mathrm{Aa}$ & $54.0 \mathrm{Aa}$ & $33.9 \mathrm{Aa}$ \\
\hline
\end{tabular}

a Different capital letters indicate significant differences between different stages for the same SAP treatment $(P<0.05)$. Different lowercase letters indicate significant differences between different SAP treatments in the same stage $(P<0.05)$.

observed in SWC. In addition, the spraying treatments of SAPs were more effective in water retention than the bulk treatments.

\subsection{Abundance of bacteria in the soil}

The abundance of bacteria, determined as the number of $16 \mathrm{~S}$ rRNA gene copies per gram dry soil, varied greatly among the stages of wheat growth and SAP treatments (Fig. 4). In the jointing stage, the JC-B treatment significantly increased the bacterial 16S rRNA gene copy numbers, while the opposite was observed in the JS-B treatment. In both the booting and filling stages, the bacterial $16 \mathrm{~S}$ rRNA gene copy numbers in all SAP treatments were significantly higher than those in the two controls, respectively (Fig. 4). Over the three growth stages, the highest bacterial 16S rRNA gene copies were observed in the booting stage for all treatments $(P<0.05)$.

\subsection{Soil MBC and $S M R$}

There were significant differences in microbial activity among the different stages $(P<0.05)$ (Fig. 5). Microbial activity, characterized by MBC and SMR, was highest in the booting stage, showing a similar trend as the bacterial abundance. Meanwhile, the JC

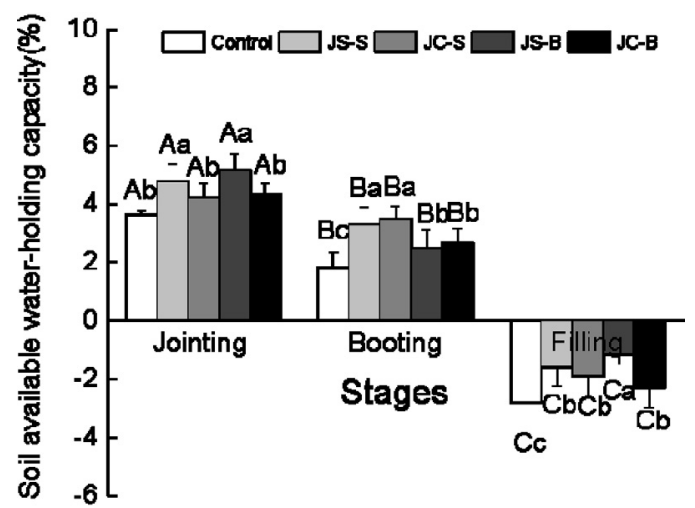

Fig. 3. Soil available water-holding capacity (AWC) in different stages and under different SAP treatments. Different capital letters indicate significant differences between stages for the same SAP treatment $(P<0.05)$. Different lowercase letters indicate significant differences between SAP treatments in the same growth stage $(P<0.05)$. Small bars indicate the standard errors. treatments significantly stimulated microbial activity, as was most obvious in the booting stage, indicating that JC treatments were more beneficial for microbial activity than the control or JS treatments.

\section{Discussion}

\subsection{Effect of SAPs on the soil water and the growth of wheat}

The results of the current study clearly showed that the addition of SAPs could improve the soil water-holding capacity and allowed the soil to hold much more water. Meanwhile, SAPs also had significant impacts on SMHM, while SMHM was fixed by soil particles and could not be used by plants. The fact that SAPs increased soil water content but not soil available water content suggested that the benefit of SAPs to plant growth might be limited. This phenomenon was consistent with the results that there were almost no significant differences in wheat shoot length or grain dry weight between treatments. However, this result was very different from previous studies in both field and laboratory conditions, which

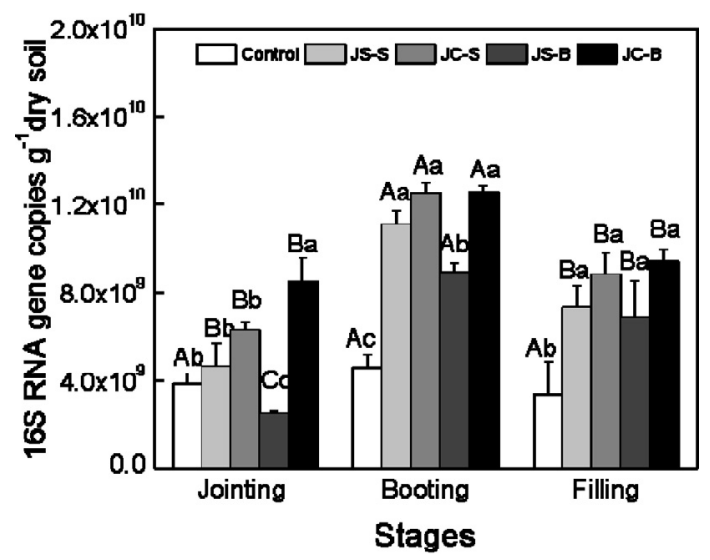

Fig. 4. Abundance of bacteria in different stages and under different SAP treatments. Different capital letters indicate significant differences between stages for the same SAP treatment $(P<0.05)$. Different lowercase letters indicate significant differences between SAP treatments in the same growth stage $(P<0.05)$. Small bars indicate the standard errors. 

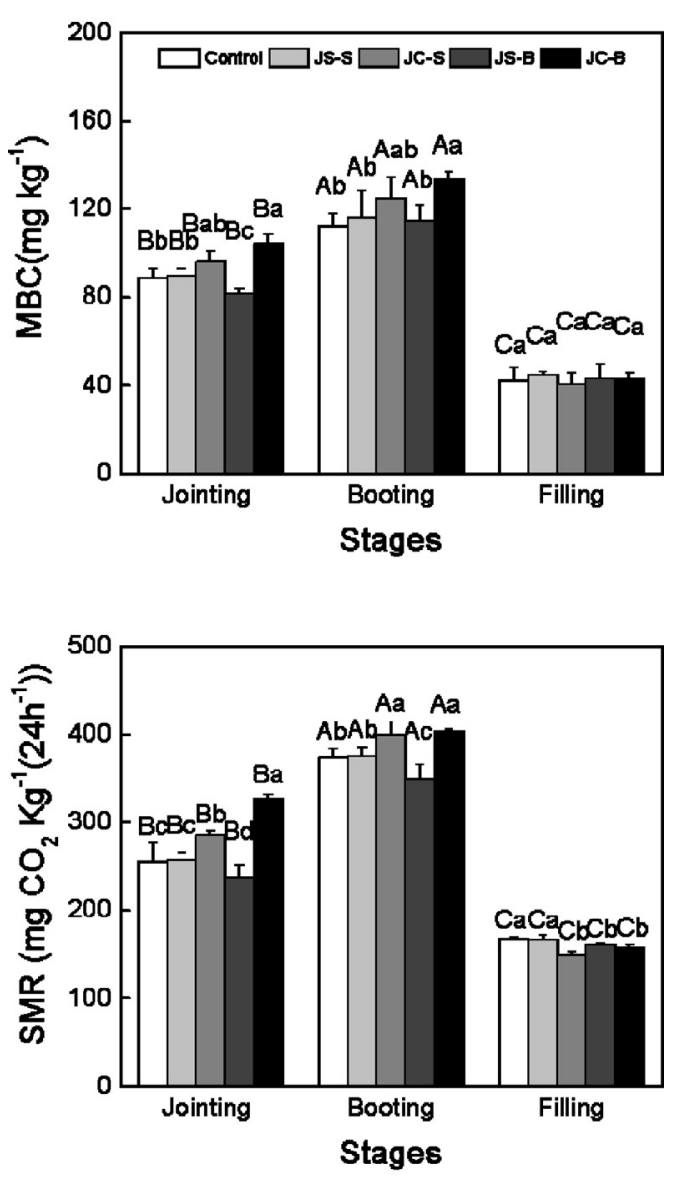

Fig. 5. Soil microbial biomass carbon (MBC) and soil microbial respiration (SMR) in different stages and under different SAP treatments. Different capital letters indicate significant differences between stages for the same SAP treatment $(P<0.05)$. Different lowercase letters indicate significant differences between SAP treatments in the same growth stage $(P<0.05)$. Small bars indicate the standard errors.

showed that SAPs could improve crop growth significantly (Yazdani et al., 2007; Islam et al., 2011b).

\subsection{Effect of SAPs on soil water-stable aggregates}

In the jointing stage, the SAP treatment had no effect on small or large aggregates. However, in the booting and filling stages, the JC and JS treatments promoted a higher proportion of large aggregates relative to the control. It had been reported that SAPs could be strongly adsorbed onto the surface of soil particles, preventing dispersion (Ajwa and Trout, 2006). However, the first sampling was only 4 days after the SAP application, so there might have been insufficient time for the SAP to bind totally with the soil particles. In the booting and filling stages, part of the SAPs would have gradually penetrated into the pores within the aggregates ( $\mathrm{Lu}$ and $\mathrm{Wu}, 2003$ ) and preserved or increased soil aggregation and pore continuity (Keren and Ben-Hur, 1997; Ajwa and Trout, 2006).

\subsection{Effect of SAPs on the abundance of bacteria}

The 16S rRNA gene can provide taxonomic information about the composition of bacterial communities (Satoshi et al., 2009). 16S rRNA genes extracted directly from the natural environment have also recently been employed to obtain insights into the extent and drivers of soil-borne microbial diversity (Tiedje et al., 1999; Torsvik and Ovreas, 2002; Rodriguez-Valera, 2004; Schloss and Handelsman, 2004). The addition of SAPs most likely significantly increased the abundance of bacteria (based on 16S RNA copy numbers) from the first to the second stage of wheat growth, suggesting that bacterial growth had been enhanced. Furthermore, surprisingly, more 16S rRNA gene copies were detected in the booting stage than in other stages. This result suggests that bacterial reproduction was enhanced by the addition of SAPs under natural environmental conditions, especially in the booting stage. Plantderived substrates, both those actively exuded and those passively dispersed, could provide the majority of food and energy for soilborne microbial communities (Marschner et al., 2004). Thus, when the plants were growing rapidly, it was likely that they produced more substrates, which led to the levels of soil microbial activity being highest in the booting stage.

\subsection{Effect of SAPs on soil microbial activities}

A significant increase in MBC and SMR was observed in the JC treatments (JC-B and JC-S) in the jointing and booting stages (Fig. 5), especially in the booting stage. JC-B had a greater effect on MBC than JC-S. High microbial biomass and activity often lead to high nutrient availability (Zaman et al., 1999; Tu et al., 2003) and may in turn lead to high plant productivity (Tu et al., 2006), which could explain the higher wheat yield produced by the JC-B treatment relative to the other treatments. Moreover, because the SAPs used in this study were extracted from plants, they might be utilized as a carbon source by soil microbes, thus explaining the higher values of MBC and SMR in the jointing and booting stages.

The significant decrease in MBC and SMR in the filling stage could be due to the changes in community structure and size, which might be the result of a change in the input of metabolizable $C$ from plant residues (Gomez et al., 2006) and soil conditions derived from plant growth influences (Patra et al., 2006). In this stage, SAPs might have been decomposed partially or completely, resulting in lower values of MBC and SMR. This effect was most obvious in the JC treatments, which significantly stimulated the microbial activities in the booting stage, accelerating the decomposition of soil organic matter. Thus, the SBR decreased more obviously in the filling stage compared with that in the control treatment because the microbes did not have access to sufficient substrates. As a result, this reduction of SBR was not related to the adverse impact of SAPs.

Based on the statements above, the application of SAPs did not show any adverse effects on the plant growth, soil physical properties or microbial properties. Soil is a complex ecosystem involving many factors, which makes it difficult to assess the environmental effects systematically and comprehensively when chemical additives are used into the soil. In any case, we need to establish an assessment framework and improve upon it over time. This framework should consist of indices related to the soil physical and chemical properties, plant growth status and soil microbial diversities (function and structure). In this study, we hope to have supplied useful information to contribute to this framework or a basis of exploration for future studies.

\section{Conclusions}

Based on a field experiment using winter wheat, our results indicate that the application of SAPs would be beneficial to the improvement of soil physical properties, which might assist in the control of water loss. At a concentration of $200 \mathrm{~kg} \mathrm{ha}^{-1}$, the SAPs strongly increased the absorption of water and the presence of water-stable aggregates. The SAPs did not lead to detectable adverse effects on the soil microbial community and might even enhance it. The influences of SAPs also depended on the application methods in the field, as only the bulk application of JC improved the yield. There were no direct relationships between 
plant properties and soil water content. Further studies may be necessary to determine the forms of soil water under the different water supply conditions using different types of soils.

\section{Acknowledgments}

This study was supported by the National Science Foundation of China $(41071163,41025004)$ and the Youth Innovation Promotion Association, Chinese Academy of Sciences.

\section{References}

Ajwa, H.A., Trout, T.J., 2006. Polyacrylamide and water quality effects on infiltration in sandy loam soils. Soil Sci. Soc. Am. J. 70, 643-650.

Al-Omran, A.M., Al-Harbi, A.R., 1997. Improvement of sandy soils with soil conditioners. In: Wallace, A., Terry, R.E. (Eds.), Handbook of Soil Conditioners: Substances that Enhance the Physical Properties of Soil. Marcel Dekker, Inc, New York, pp. 363-384.

Bai, W., Zhang, H., Liu, B., Wu, Y., Song, J., 2010. Effects of super-absorbent polymers on the physical and chemical properties of soil following different wetting and drying cycles. Soil Use Manage. 26, 253-260.

Busscher, W.J., Bjorneberg, D.L., Sojka, R.E., 2009. Field application of PAM as an amendment in deep-tilled US southeastern coastal plain soils. Soil Till. Res. 104, 215-220.

Chen, C., Condron, L.M., Davis, M., Sherlock, R.R., 2000. Effects of afforestation on phosphorus dynamics and biological properties in a New Zealand grassland soil. Plant Soil 220, 151-163.

Elliot, E.T., 1986. Aggregate structure and carbon, nitrogen, and phosphorus in native and cultivated soils. Soil Sci. Soc. Am. J. 50, 627-633.

Gomez, E., Ferreras, L., Toresani, S., 2006. Soil bacterial functional diversity as influenced by organic amendment application. Bioresour. Technol. 97, 1484-1489.

Gornall, J., Betts, R., Burke, E., Clark, R., Camp, J., Willett, K., Wiltshire, A., 2010. Implications of climate change for agricultural productivity in the early twenty-first century. Philos. Trans. R. Soc. B: Biol. Sci. 365, 2973-2989.

Gupta, S.C., Larson, W.E., 1979. Estimating soil water retention characteristics from particle size distribution, organic matter percent and bulk density. Water Resour. Res. 15, 1633-1635.

He, J.Z., Shen, J.P., Zhang, L.M., Zhu, Y.G., Zheng, Y.M., Xu, M.G., Di, H.J., 2007. Quantitative analyses of the abundance and composition of ammonia-oxidizing bacteria and ammonia-oxidizing archaea of a Chinese upland red soil under long-term fertilization practices. Environ. Microbiol. 9, 2364-2374

Islam, M.R., MaoSS, Xue, X.Z., Eneji, E.A., Zhao, X.B., Hu, Y.G., 2011a. A lysimeter study of nitrate leaching, optimum fertilisation rate and growth responses of corn (Zeamays L.) following soil amendment with water-saving super-absorbent polymer. J. Sci. Food Agric. 91, 1990-1997.

Islam, M.R., Hu, Y., Mao, S., Jia, P., Eneji, A.E., Xue, X., 2011b. Effects of water-saving superabsorbent polymer on antioxidant enzyme activities and lipid peroxidation in corn (Zeamays L.) under drought stress. J. Sci. Food Agric. 91, 813-819.

Jonasson, S., Michelsen, A., Schmidt, I.K., Nielsen, E.V., 1996. Microbial biomass C N and $\mathrm{P}$ in two arctic soils and responses to addition of NPK fertilizer and sugar: implications for plant nutrient uptake. Oecologia 106, 507-515.

Keren, R., Ben-Hur, M., 1997. Polymer effects on water infiltration and soil aggregation. Soil Sci. Soc. Am. J. 61, 565-570.
Lentz, R.D., Sojka, R.E., 1994. Field result using polyacrylamide to manage furrow erosion and infiltration. Soil Sci. 158, 274-282.

Lentz, R.D., Sojka, R.E., Robbins, C.W., 1998. Reducing phosphorus losses from surface-irrigated fields: emerging polyacrylamide technology. J. Environ. Qual. $27,305-312$.

Lu, J.H., Wu, L.S., 2003. Polyacrylamide distribution in columns of organic matterremoved soils following surface application. J. Environ. Qual. 32, 674-680.

Marschner, P., Crowley, D., Yang, C.H., 2004. Development of specific rhizosphere bacterial communities in relation to plant species, nutrition and soil type. Plant Soil 261, 199-208.

Nadler, A., Perfect, E., Kay, B.D., 1996. Effect of polyacrylamide application on the stability of dry and wet aggregates. Soil Sci. Soc. Am. J. 60, 555-561.

Patra, A.K., Abbadie, L., Clays-Josserand, A., Degrange, V., Grayston, S.J., 2006. Effects of management regime and plant species on the enzyme activity and genetic structure of $\mathrm{N}$-fixing, denitrifying and nitrifying bacterial communities in grassland soils. Environ. Microbiol. 8, 1005-1016.

Rinnan, R., Michelsen, A., Jonasson, S., 2008. Effects of litter addition and warming on soil carbon, nutrient pools and microbial communities in a subarctic heath ecosystem. Appl. Soil Ecol. 39, 271-281.

Rodriguez-Valera, F., 2004. Environmental genomics, the big picture? FEMS Microbiol. Lett. 231, 153-158.

Satoshi, I., Michihiro, Y., Mami, K., 2009. Microbial populations responsive to denitrification-inducing conditions in rice paddy soil, as revealed by comparative 16S rRNA gene analysis. Appl. Environ. Microbiol. 75, 7070-7078.

Schloss, P.D., Handelsman, J., 2004. Status of the microbial census. Microbiol. Mol. Biol. Rev. 68, 686-691.

Sojka, R.E., Lentz, R.D., Westermann, D.T., 1998. Water and erosion management with multiple applications of polyacrylamide in furrow irrigation. Soil Sci. Soc. Am. J. 62, 1672-1680.

Sojka, R.E., Entry, J.A., 2000. Influence of polyacrylamide application to soil on movement of microorganisms in runoff water. Environ. Pollut. 108, 405-412.

Suzuki, M.T., Taylor, L.T., DeLong, E.F., 2000. Quantitative analysis of small-subunit rRNA genes in mixed microbial populations via 5'-nuclease assays. Appl. Environ. Microbiol. 66, 4605-4614

Tiedje, J.M., Asuming-Brempong, S., Nusslein, K., Marsh, T.L., Flynn, S.J., 1999. Opening the black box of soil microbial diversity. Appl. Soil Ecol. 13, 109-122.

Torsvik, V., Ovreas, L., 2002. Microbial diversity and function in soil: from genes to ecosystems. Curr. Opin. Microbiol. 5, 240-245.

Tu, C., Koenning, S.R., Hu, S., 2003. Root-parasitic nematodes enhance soil microbial activities and nitrogen mineralization. Microbial. Ecol. 46, 134-144.

Tu, C., Koenning, S.R., Hu, S., 2006. Soil microbial biomass and activity in organic tomato farming systems: effects of organic inputs and straw mulching. Soil Biol. Biochem. 38, 247-255.

Vance, E.D., Brookes, P.C., Jenkinson, D.S., 1987. An extraction method for measuring microbial biomass C. Soil Biol. Biochem. 22, 703-707.

Wallace, J.S., 2000. Increasing agricultural water use efficiency to meet future food production. Agric. Ecosyst. Environ. 82, 105-110.

Yazdani, F., Allahdadi, I., Akbari, G.A., 2007. Impact of superabsorbent polymer on yield and growth analysis of soybean (Glycine $\max$ L.) under drought stress condition. Pak. J. Biol. Sci. 10, 4190-4196.

Zaman, M., Di, H.J., Cameron, K.C., 1999. A field study of gross rates of N mineralization and nitrification and their relationships to microbial biomass and enzyme activities in soils treated with dairy effluent and ammonium fertilizer. Soil Use Manage. 15, 188-194.

Zhang, X.C., Miller, W.P., 1996. Polyacrylamide effect on infiltration and erosion in furrows. Soil Sci. Soc. Am. J. 60, 866-872. 